О.М. Жарик ${ }^{1}$, А.В. Тристан ${ }^{2}$

${ }^{1}$ Командування Повітряних Сил Збройних Сил Украӥни, Вінниия

${ }^{2}$ Харківський національний університет ім. І. Кожедуба, Харків

\title{
ПОВІТРЯНА ОПЕРАЦІЯ У ВІЙСЬКОВИХ КОНФЛІКТАХ СУЧАСНОСТІ
}

В статті визначені основні тендениії розвитку повітряних операщій у війнах (військових конфліктах) минулого та сучасності. Доведено, щуо переміщення збройної боротьби у повітряний простір піднімає роль авіаційної та протиповітряної компоненти збройних сил, від ефективності застосування яких буде залежати ступінь досягнення стратегічної мети воєнних дій. Наголошується, щзо повітряна операція є важливим компонентом операції з відсічі збройної агресії. Визначено, щзо сучасна концепція повітряної операції має вплинути на розвиток воєнного мистецтвва, організацію підготовки, подальше реформування $і$ розвиток Збройних Сил Украӥни та дозволить якісно реформувати Повітряні Сили та прискорити вступ України до НАТО. Основою успішного проведення повітряної операції є завоювання переваги у повітрі. Втрата переваги у повітрі ставить під сумнів успішність операџії сил оборони держави з відсічі збройної агресії. За умови, якщо авіація та ППО, інші сили і засоби угруповання об'єднаних сил (сил оборони) будуть здатні виконати свої завдання в повітряній оборонній операції-тобто в операції з боротьби за перевагу в повітрі з оборонними цілями, то і угруповання Сухопутних військ будуть мати мінімальні втрати, збережуть свої бойові спроможності та будуть здатні виконати завдання в оборонній (наступальній або контрнаступальній) операції, інших операціях Об'єднаних сил.

Ключові слова: військові конфлікти, перевага (панування) в повітрі, повітряна операція, Повітряні Сили Збройних Сил Украӥни, система операџій.

\section{Вступ}

Особливість XXI століття полягає в тому, що значна частина локальних війн та збройних конфліктів відбувалася (та відбувається) між противниками, які знаходяться на різних рівнях розвитку збройних сил не тільки у технічному відношенні (Сирія, Лівія), але й у формах і способах застосування військ (сил) (Вірменія - Азербайджан). Значимою тенденцією війн та збройних конфліктів $є$ прагнення збереження живої сили за рахунок заміни людини високотехнологічними бойовими засобами. Отже, противник 3 високою ймовірністю розпочне операцію (бойові дії) проти України безпосередньо 3 застосування ракетного озброєння та авіації шляхом ведення повітряної наступальної операції. Переміщення збройної боротьби у повітряний простір піднімає роль авіаційної та протиповітряної компонент збройних сил, від ефективності застосування яких буде залежати ступінь досягнення стратегічної мети воєнних дій. Таким чином, повітряна операція (як з оборонними, так і з наступальними цілями) є важливим компонентом операції з відсічі збройної агресії. Розвиток доктринальної бази застосування Збройних Сил України, приведення ii до принципів, викладених у нормативних документах НАТО, трансформація системи управління, вимагають подальшого розвитку теорії повітряної операції як важливої складової операції з відсічі збройної агресії.
Аналіз останніх досліджень і публікацій. Проводячи аналіз літературних джерел, які були використані при написанні статті, слід їх умовно розділити на декілька груп.

До першої групи слід віднести ретроспективні теоретичні роботи з розвитку повітряних операцій [1-4], які використані для розуміння змісту та сутності розвитку теорії повітряної операції.

До другої групи віднесемо теоретичні роботи 3 розвитку теорії повітряних операцій [5-8], а також теоретичні роботи 3 аналізу сучасних війн та збройних конфліктів та основних тенденцій їх розвитку [9-13].

До третьої групи слід віднести доктринальну базу з планування та ведення повітряних операцій в країнах НАТО та сучасну доктринальну базу Повітряних Сил [14-15].

Мета статті - обгрунтування ролі та місця повітряної операції у системі операцій на основі ретроспективного аналізу та аналізу війн (збройних конфліктів) сучасності.

\section{Виклад основного матеріалу}

\section{I. Складові досягнення мети війни та збройного конфлікту}

Діючі стратегічні та оперативні концепції розвинених країн світу в тій або іншій формі визначають, що у збройному конфлікті або війні боротьба буде включати чотири основні етапи (рис. 1) [7]. 


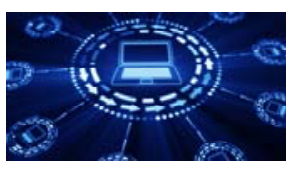

1. Завоювання переваги в інформаційному та кіберпросторі

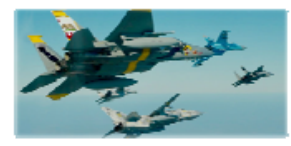

\section{2. Завоювання переваги в повітрі}
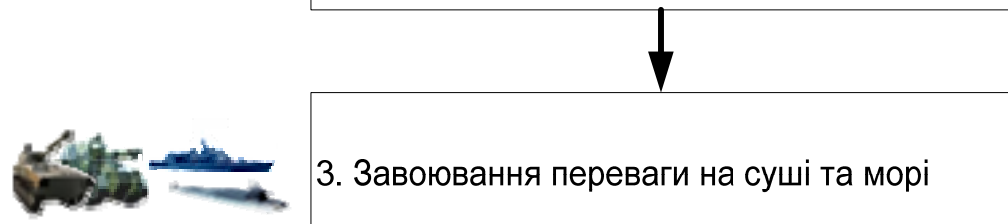

3. Завоювання переваги на суші та морі

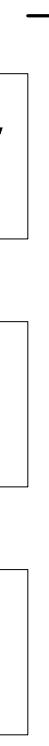

\section{4. Досягнення} мети війни (збройного конфллікту)

Рис. 1. Чотири складові досягнення мети збройного конфлікту (війни) Джерело: розроблено авторами.

Перший етап полягатиме у завоюванні ініціативи й переваги в інформаційній сфері (у домінуючому впливі на суспільну свідомість, на систему управління військами й зброєю).

Другий етап, зміст якого буде полягати у завоюванні панування (переваги) у повітряно-космічній cфepi.

Третій етап передбачає завоювання переваги на морі та суші з розгромом або істотним ослабленням угруповань військ (сил) противника.

Четвертий - завершальний етап, у ході якого повинен бути закріплений досягнутий успіх та створені умови для реалізації поставлених політичних цілей.

Аналіз рис. 1 свідчить, що завоювання переваги (панування) в повітрі є першим військовим (збройним) етапом у досягненні цілей війни.

Як відомо, військові конфлікти розвиваються в межах одного театру воєнних дій, однак, із широким використанням сил і засобів, розміщених за його межами. Можна допустити, що такий підхід збережеться і у майбутньому, виходячи з концепції проектування сили в одній точці. Отже, успіх у військовому конфлікті (війні) можна досягти лише проведенням об'єднаної операції в різних фізичних просTopax.

\section{II. Історія та еволюція повітряних операцій}

Ретроспективний погляд на еволюцію теорії операцій свідчить, що траєкторія іiі розвитку залежить від єдності у часі, просторі та змісті збройної боротьби, що розширюється: від стратегії генерального бою в одній точці в епоху наполеонівських війн та лінійної стратегії в другій половині XIX початку XX століття - до глибокої операції на кон- тинентальному театрі воєнних дій напередодні та у роки другої світової війни і, далі, до об'єднаної (кібернетичної, інформаційної, космічної, спеціальної, повітряної, наземної, морської) операції.

Як свідчить історія, теорія та практика повітряних операцій постійно оновлюються, їх показники змінюються в залежності від організаційної структури та бойового складу військово-повітряних сил (ВПС), авіаційних засобів ураження, характеру та масштабу застосування сил оборони держави в цілому [6].

Еволюційно теорія повітряних операцій почала розвиватися з початком широкого застосування авіації на полі бою.

Основи теорії підготовки та проведення повітряної операції почали складатися у 30 -х роках [1]. Так, у радянських збройних силах наприкінці 1932 року перед ВПС вперше було поставлене завдання щодо розробки питань підготовки та ведення повітряних операцій [2]. Вони розглядалися як самостійні операції ВПС.

Ще в 1933 році у Радянському Союзі були створені перші окремі авіаційні корпуси, а в 1936 році - повітряні армії особливого призначення для вирішення оперативних завдань у глибокому тилу противника.

Передбачалось, що основною формою їх застосування буде проведення повітряних операцій $з$ метою руйнування воєнно-промислових об'єктів у глибокому тилу противника [3].

За поглядами радянського воєнного мистецтва, що склалися напередодні Другої світової війни, також вважалося, що повітряні операції в інтересах завоювання панування в повітрі повинні проводитись самостійно, носити рішучий характер, вестися 
на велику глибину і на широкому фронті. Таким чином, у передвоєнний період фахівцями воєнного мистецтва СРСР були розроблені загальні положення і рекомендації щодо підготовки та ведення самостійних операцій ВПС [4].

3 початком війни через складності стратегічної обстановки на радянсько-германському фронті ВПС не проводили повітряні операції, а зосереджували основні зусилля на ураженні німецько-фашистських військ і об'єктів комунікацій у тактичній і ближній оперативній глибині шляхом завдання окремих авіаційних ударів. Інтенсивно повітряні операції ВПС стали застосовувати після 1943 року. Протягом війни ВПС було проведено 15 повітряних операцій. Доречно відмітити, що ще на початку війни повітряна операція розглядалась, як основна форма застосування ВПС, а бойові дії - як невід'ємна частина воєнних дій, які проводились в проміжках між повітряними операціями.

Першочергове і головне значення мали повітряні операції, які проводились 3 метою завоювання панування у повітрі (8 з 15 проведених операцій цього періоду). У чотирьох проведених повітряних операціях ставилось завдання розгромити оперативні резерви i порушити комунікації противника, у трьох - підірвати його воєнно-економічний поте-нціал.
Усі операції носили тільки наступальний характер.

Після закінчення війни теорія і практика повітряних операцій продовжувала розвиватися. До середини 70-х років повітряні операції розглядалися як самостійні операції, які проводились у межах стратегічних операцій і були їх складовими частинами. На початку 80-х років XX століття вказувалося на необхідність залучення до повітряних операцій угруповань Сухопутних військ, Військ протиповітряної оборони та Військово-Морського Флоту. У подальшому повітряна операція розглядалася на театрі воєнних дій, як спільна (об’єднана) операція всіх видів ЗС при вирішальній ролі ВПС. Цей час слід вважати початком розробки теорії якісно нових операцій - спільних повітряних операцій на театрі воєнних дій.

Таким чином, радянська воєнна наука до 1980 року дійшла висновку про те, що успішне проведення сучасної повітряної операції можливо лише спільними діями ВПС, авіації Військово-Морських Сил (ВМС), основних сил і засобів ППО, частини сил загальновійськових об'єднань і з'єднань $\mathrm{PBiA}$ та радіоелектронної боротьби (РЕБ).

Умовне позначення еволюції повітряних операцій наведено на рис. 2.

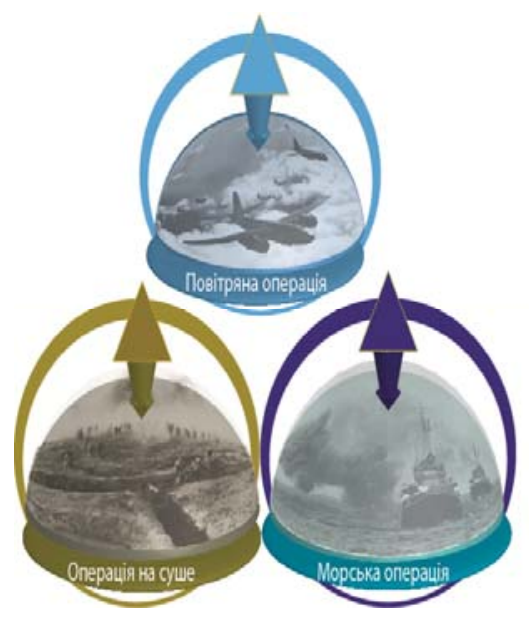

а) до 50-х років XX ст.

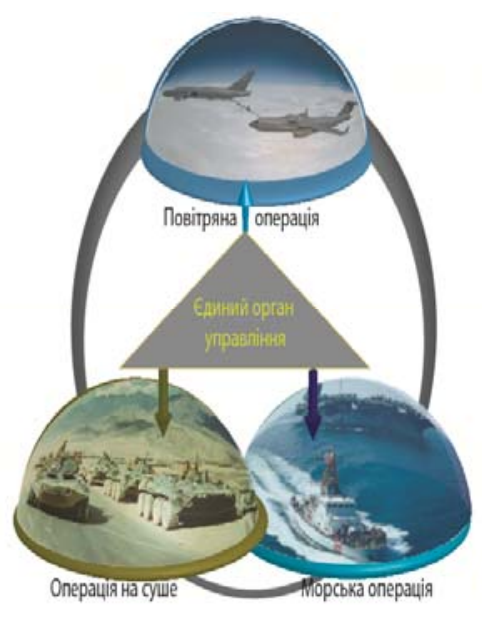

б) 50-90-ті pp. ХX ст.

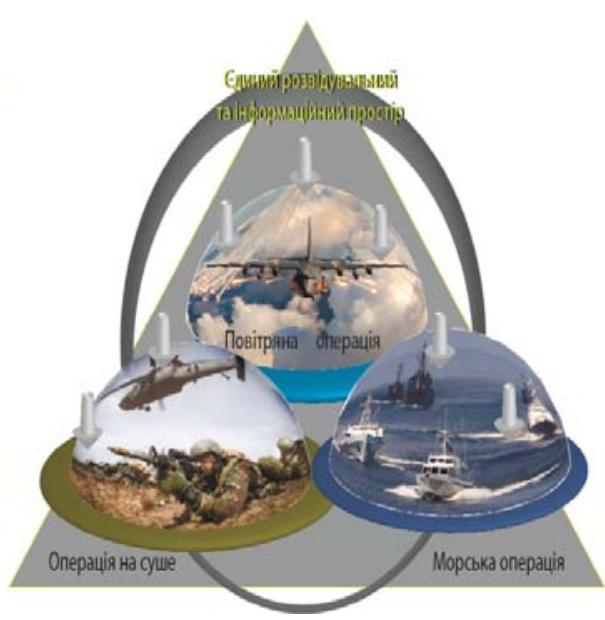

в) XXI ст.

Рис. 2. Еволюція трансформації повітряної операції Джерело: розроблено авторами.

У подальшому зі стрімким розвитком авіаційної техніки та озброєння, ВПС стали застосовуватися все частіше у воєнних конфліктах різної інтенсивності, як основна ударна сила для вирішення поставлених завдань.

\section{III. Особливості ведення повітряної операції сучасності}

Розглянемо послідовність проведення повітряних та наземних фаз операцій в останніх локальних війнах та збройних конфліктах.
По-перше, це військова операція Багатонаціональних коаліційних сил на чолі з США, складова частина війни в Перській затоці 1990-1991 років, коли понад 1000 бойових літаків Коаліційних сил, які базувалися як на наземних військово-повітряних базах, так і на 6 авіаносцях, завдавали масованих ударів 3 повітря. 24 лютого почалася друга фаза операції - наступ наземних сил і за 4 доби територія Кувейту була визволена [12].

По-друге, це військова операція НАТО проти Союзної Республіки Югославія в період з 24 березня 
по 10 червня 1999 року. У ході операції спостерігалась тільки повітряна фаза.

По-третє, це військовий конфлікт в Афганістані (3 7 жовтня 2001 року), який почався наземними ударами важких бомбардувальників, літаків палубної авіації, а також крилатих ракет з американських i британських кораблів та підводних човнів.
Закінчилося все наземною фазою.

При цьому, у ході останнього конфлікту в Нагірному Карабасі повітряна операція проводилася 3 першого по останній день [9].

Ці обставини свідчать про виключну важливість повітряної операції для досягнення мети війни (збройного конфлікту) (рис. 3).

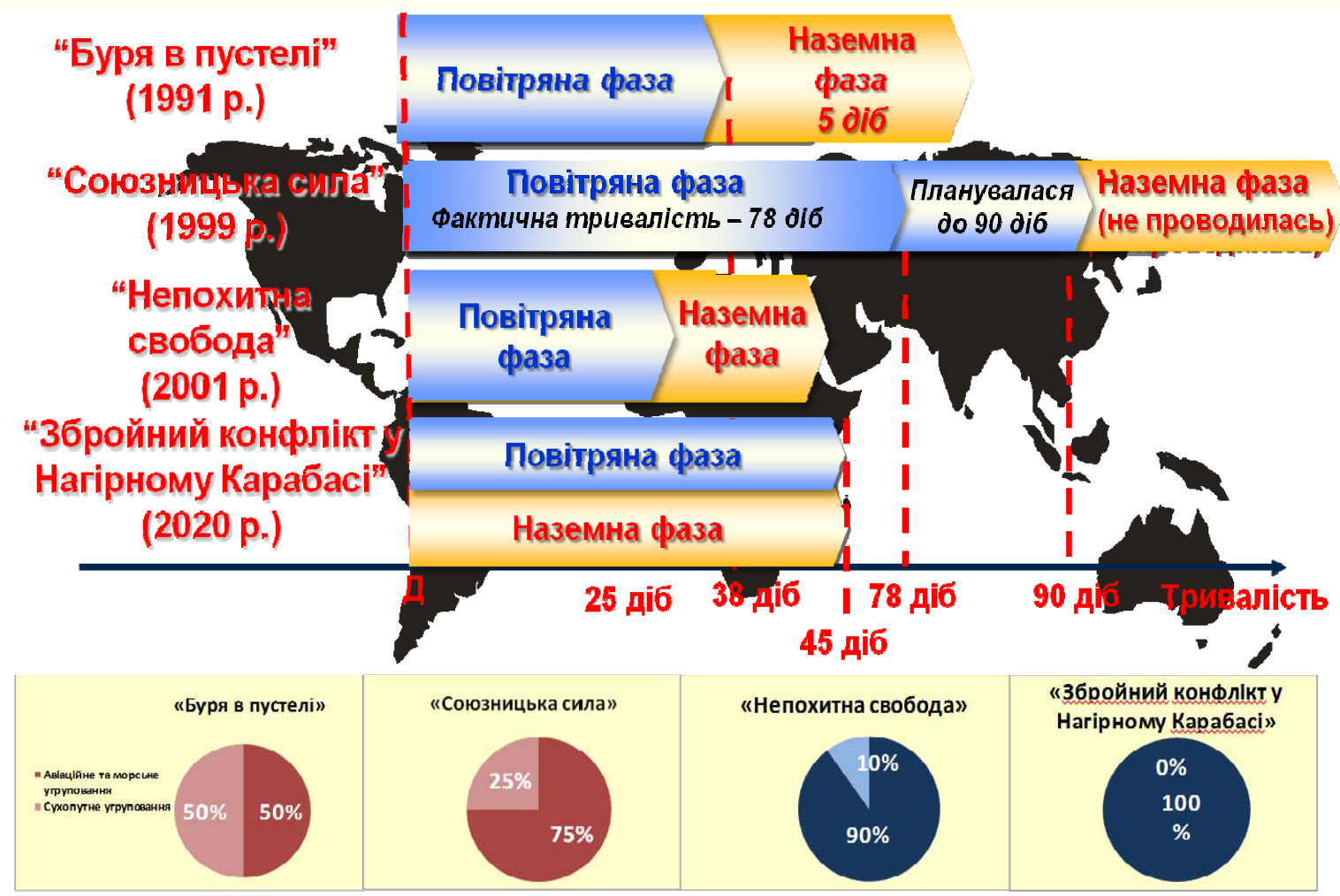

Рис. 3. Повітряні операції в сучасних війнах та збройних конфліктах Джерело: розроблено авторами.

Більш детально зупинимося на особливостях ведення повітряної операції у Нагірному Карабасі.

У цьому конфлікті Збройні сили Азербайджану застосували всі компоненти повітряної наступальної операції. Це [9]:

- по-перше, знищення системи ППО противника;

- по-друге, вогневе ураження критичних елементів противника на всю глибину його оперативної побудови та в глибокому тилу;

- по-третє, ведення ППО для оборони (прикриття) своїх військ;

- по-четверте, безпосередня авіаційна підтримка військ (сил) у наступі.

Така комплексність стала можлива тільки завдяки застосуванню авіації, в тому числі і безпілотної. Аналіз бойових втрат Вірменії показує, що від 60 до 90 \% завдань вогневого ураження було покладено на авіацію 3С Азербайджану, незважаючи на наявність достатньо потужного угруповання ракетних військ та артилерії. Азербайджан зробив головне - він адаптував основні принципи, форми і спо- соби застосування складових власних ЗС до вимог даного збройного конфлікту, а авіація (пілотована та безпілотна) забезпечила перемогу в ньому (рис. 4). Вірменія, яка обмежила застосування авіації завданнями ППО, програла [9].

Особливості ведення повітряних операцій збройними силами країн-членів НАТО та їх етапи представлені на рис. 5:

- ліва частина рис. 5 - проводиться повітряна оборонна операція, тобто здійснюється відбиття ударів засобів повітряного нападу противника (зрив повітряної наступальної операції), прикриття від ударів 3 повітря важливих державних і військових об’єктів, угруповань військ (сил);

- права частина рис. 5 - проводиться повітряна наступальна операція, яка містить дві складові:

- повітряна операція 3 авіаційної підтримки, яка діє на тактичній, оперативно-тактичній і оперативній глибині;

- стратегічна повітряна операція, яка діє на стратегічну глибину. 

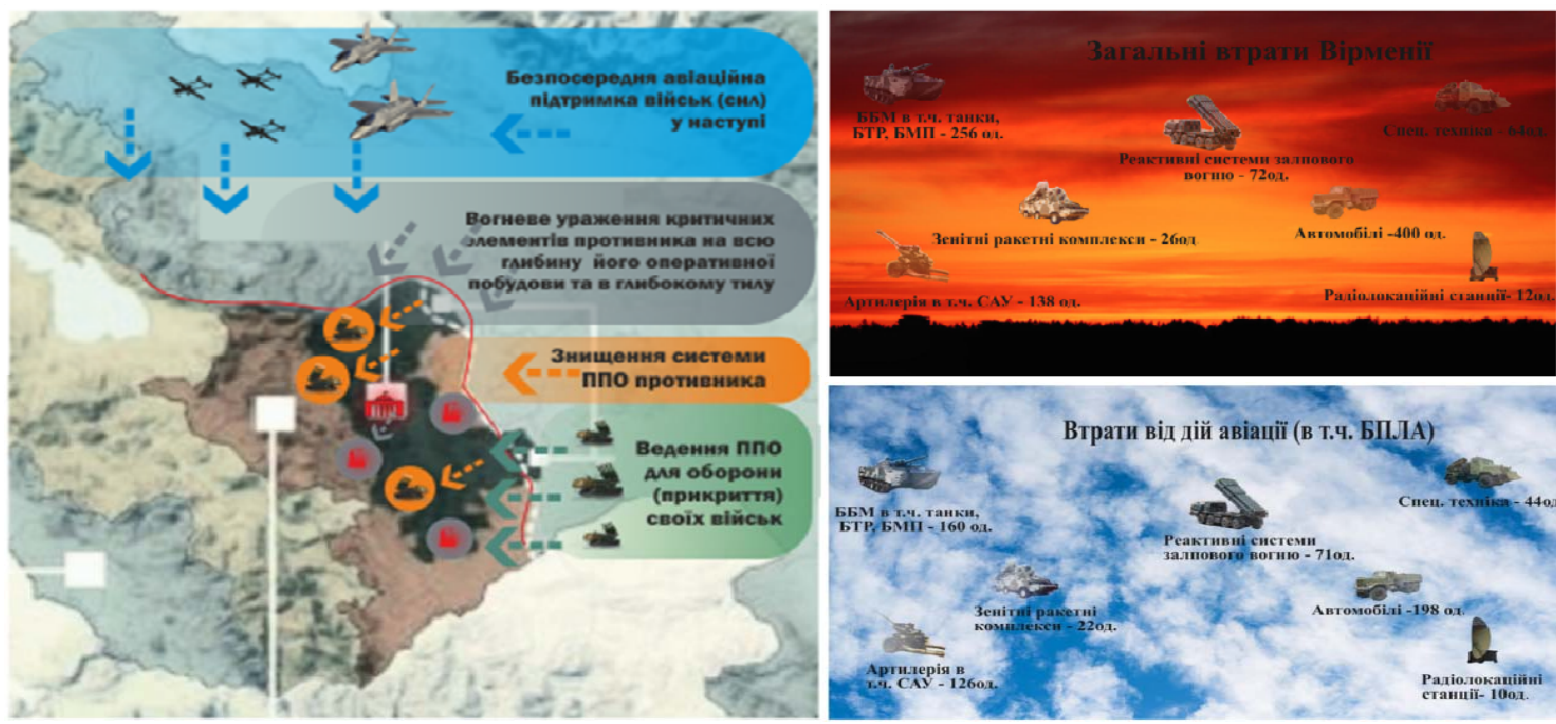

Рис. 4. Аналіз ведення повітряної операції у Нагорному Карабасі (2020 рік)

Джерело: розроблено авторами за даними [10].

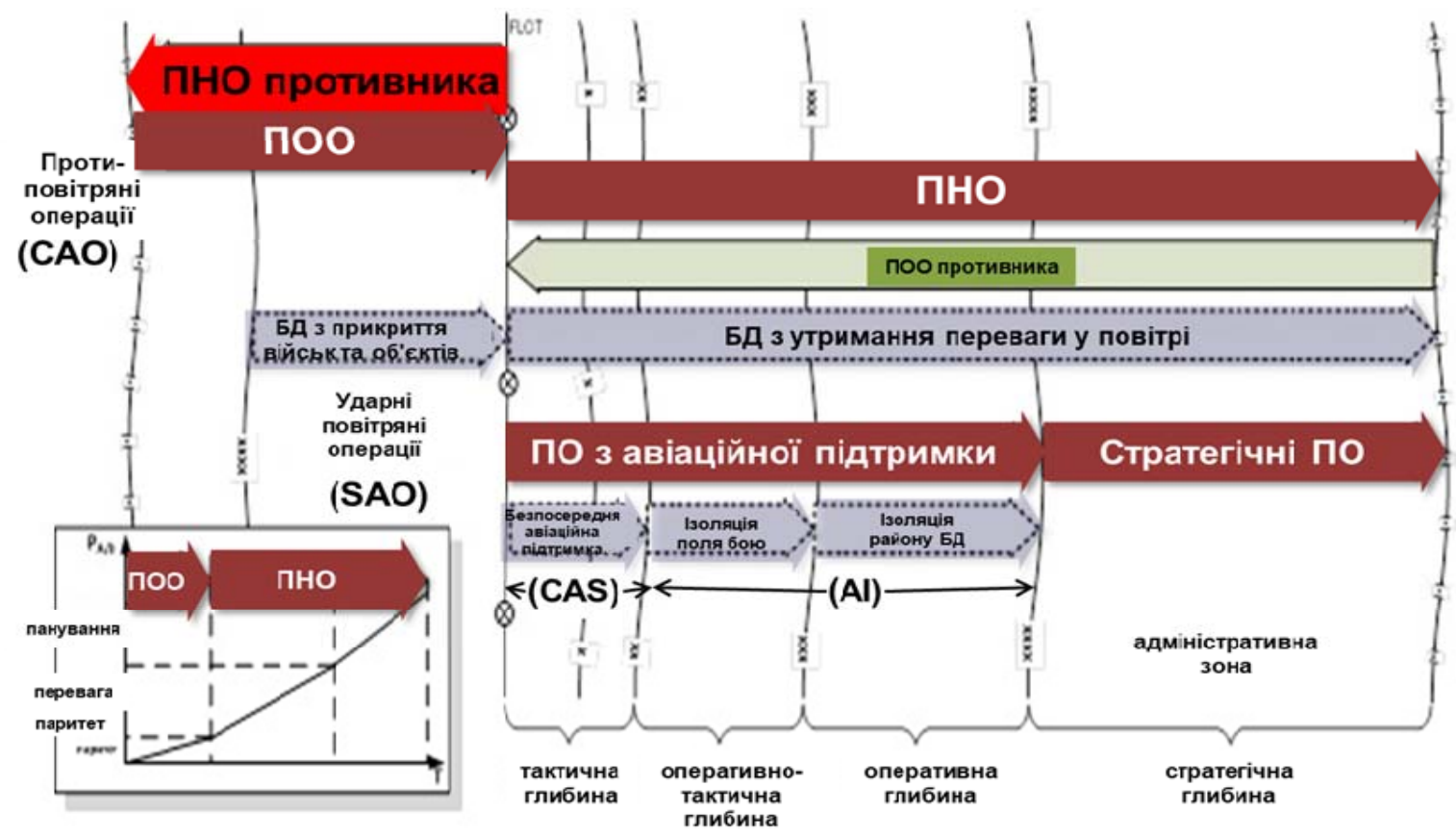

Рис. 5. Особливості ведення повітряних операцій збройними силами країн-членів НАТО Джерело: розроблено авторами за даними [8].

Повітряна оборонна операція проводиться до досягнення паритету у повітрі. Повітряна операція 3 авіаційної підтримки проводиться до досягнення переваги в повітрі. Стратегічна повітряна операція проводиться до досягнення панування у повітрі.

\section{IV. Роль та місце повітряної операції в системі операції Збройних Сил України}

Повітряна операція розглядається як сукупність узгоджених і взаємопов'язаних за метою, завданнями, місцем і часом боїв, ударів, бойових та спеціальних дій i маневру створеного угруповання об’єднаних сил при вирішальній ролі ПС ЗС України, які проводяться за єдиним замислом і планом під керівництвом Командувача об'єднаних сил 3С України 3 метою відбиття (зриву) повітряного нападу противника, завдання ураження його важливим об'єктам і угрупованням та створення сприятливих умов для успішного виконання завдань протиповітряної оборони, проведення операції сил оборони (об'єднаних сил).

Повітряна операція є складовою операції сил оборони. Необхідними умовами для проведення повітряної операції є: 
- наявність стратегічної або оперативної мети воєнних дій;

- обов'язковість безпосереднього зіткнення сил та засобів своїх військ і противника у формах боїв, ударів, бойових дій у повітрі;

- залучення декількох об'єднань, з'єднань (військових частин, підрозділів) різних видів 3С України;

- наявність єдиного замислу і плану, що передбачає узгодженість замислів і планів дій підпорядкованих військ (сил), які беруть участь в операції сил оборони (операції об’єднаних сил).

Мета повітряної операції досягається послідовним та/або одночасним виконанням низки операти- вних завдань. У виконанні оперативних завдань разом із ПС беруть участь сили і засоби інших видів, окремих родів військ (сил) ЗС України, а також інших складових об'єднаних сил (сил оборони).

Розвиток доктринальної бази застосування Збройних Сил України, що враховує сучасні вимоги керівних документів та стандартів, які прийняті у державах-членах НАТО, принципи планування та управління операціями, трансформація системи управління вимагають розвитку теорії повітряної операції як надважливої складової операції сил оборони з відсічі збройної агресії, ліквідації (локалізації, нейтралізації) збройного конфлікту.

Типи повітряної операції наведені на рис. 6 .

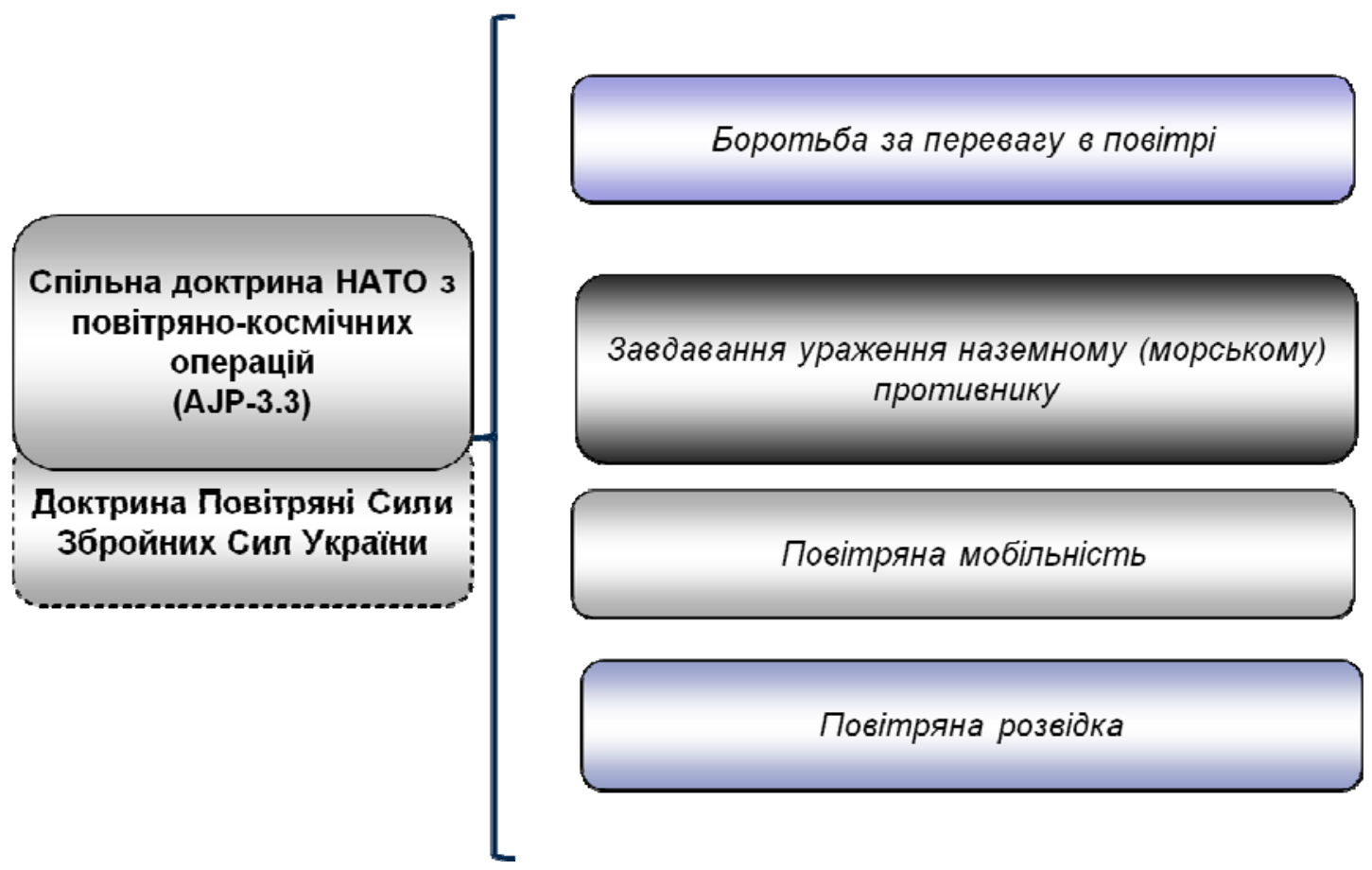

Рис. 6. Типи повітряної операції Джерело: розроблено авторами.

Повітряні операції з боротьби за перевагу в повітрі - повітряні операції, основною метою та змістом яких $є$ руйнування, подавлення або знищення повітряних і ракетних спроможностей противника, що дозволяє іiі сухопутним, військово-морським та повітряним силам вести операції і діяти в певний час і визначеному місці без суттєвого втручання (в першу чергу авіації) протилежної сторони [14-15]. Операції з боротьби за перевагу в повітрі складаються 3 підтипів: повітряної оборонної операції та повітряної наступальної операції.

Другий тип повітряних операцій - це повітряні операції щодо завдавання ураження наземному (морському) противнику. Завдавання ураження противнику 3 повітря $є$ фундаментальною характеристикою повітряної міці щодо впливу на противника 3 метою зміни його поведінки або перебігу подій.
Повітряна мобільність забезпечує можливість швидкого розгортання (доставки), забезпечення та евакуації військового та цивільного персоналу і матеріальних засобів повітрям і має вирішальне значення для успіху спільних операцій. На оперативному рівні операції повітряної мобільності поділяються на дві основні категорії: повітряні перевезення та дозаправка в повітрі.

Повітряна розвідка є найбільш інформативним видом розвідки, що забезпечує бойові дії авіації та інших видів і родів військ ЗС України даними про протидіючі угруповання противника та геотопографічні характеристики району бойових дій. На сьогодні близько 65 \% всіх необхідних розвідувальних даних добуваються за допомогою розвідувальних літальних апаратів, які можуть діяти незалежно від часу доби, пори року та метеорологічних умов. 
Система управління, яка створюється для виконання завдань повітряної операції - це сукупність розгорнутих на землі, на морі, в повітряному просторі об'єднаних функціональними зв'язками органів i пунктів управління, які забезпечують єдине управління військами, силами і засобами.

Головною вимогою до системи управління $є$ забезпечення виконання завдань повітряної операції в районі ведення воєнних (бойових) дій.

Система управління будується за централізованим принципом та повинна забезпечувати можливість включення до іiі складу органів управління всіх складових сил оборони, які залучаються до проведення повітряної операції.

Управління військами (силами) в ході повітряної операції здійснюється Командувачем об'єднаних сил ЗС України.

Безпосереднє управління частинами (підрозділами), які залучаються до проведення повітряної операції, повинен здійснювати командувач операційного Командування ПС ЗС України через пункти управління повітряних командувань (ПвК) та оперативних (оперативно-тактичних) угруповань у визначених зонах відповідальності.

У разі залучення до участі в операції одного повітряного командування безпосереднє управління частинами (підрозділами), які залучаються до проведення повітряної операції, також може здійснювати командувач ПвК.

Взаємодія в ході проведення повітряної операції у визначеній операційній зоні (районі) досягається шляхом проведення комплексу заходів 3 боку командувача об'єднаних сил та командувача операційного командування ПС ЗС України, спрямованих на упорядкування дій підпорядкованих та взаємодіючих військ (сил) для створення сприятливих умов або отримання бажаного результату операції (бойових дій).

\section{Висновки}

1. Сучасна концепція повітряної операції має вплинути на розвиток воєнного мистецтва, організацію підготовки, подальше реформування і розвиток
Збройних Сил України та дозволить якісно реформувати Повітряні Сили та прискорити вступ України до НАТО.

2. Повітряна операція $є$ важливою складовою операції сил оборони держави, що може проводитися в ході операції об'єднаних сил на основному напрямку та операцій об'єднаних сил на інших напрямках.

3. Основою успішного проведення повітряної операції є завоювання переваги у повітрі. Втрата переваги у повітрі ставить під сумнів успішність операції сил оборони держави з відсічі збройної агpeciï.

4. За умови, якщо авіація та ППО, інші сили і засоби угруповання об'єднаних сил (сил оборони) будуть здатні виконати свої завдання в повітряній оборонній операції - тобто в операції з боротьби за перевагу в повітрі з оборонними цілями, то і угруповання Сухопутних військ будуть мати мінімальні втрати, збережуть свої бойові спроможності та будуть здатні виконати завдання в оборонній (наступальній або контрнаступальній) операції, інших операціях об'єднаних сил. В іншому випадку - противник або досягне стратегічної мети і конфлікт буде вичерпаний вже на початковому етапі, або не залишиться сил і засобів для виконання завдань в ході реалізації наземної частини оборонної операції. За умови виконання завдання наступної повітряної операції або переведення першої повітряної операції у фазу наступальної повітряної операції (повітряної операції з наступальними цілями), повітряної операції із завдання ураження наземному (морському) противнику - противник отримує ураження в різних фізичних середовищах протиборства та може відмовитися від подальшої агресії.

5. Перспективами подальших досліджень є уточнення поглядів на застосування Повітряних Сил Збройних Сил України в сучасних умовах ведення збройної боротьби та трансформації планування протиповітряної оборони в операції з відсічі збройної агресії до планування повітряної операції, як складової операції сил оборони.

\section{Список літератури}

1. Дуэ Дж. Господство в воздухе / Дж. Дуэ. - М.: Воениздат НКО СССР, 1936. - 109 с.

2. Семенчиков В.И. К вопросу о развитии теории воздушных операцій / В.И. Семенчиков, Г.И. Брюховский // Военная мысль. - 1982. - № 4. - С. 15-24.

3. Андреев А.П. Воздушные операции на континентальном ТВД: монография / А.П. Андреев. - М.: Воениздат, 1984. $-251 \mathrm{c}$.

4. Жиров А.Ю. Основы применения объединений ВВС в совместных и самостоятельных операциях / А.Ю. Жиров. - Монино: ВВА, 1987. - 96 с.

5. Аналіз практики проведення операцій НАТО з підтримання миру і безпеки / Р.І. Тимошенко, Д.Л. Федянович, М.I. Шпура, Н.М. Андріянова // Збірник наукових праць Центру воєнно-стратегічних досліджень НУОУ ім. Івана Черняховського. - 2017. - № 3. - С. 18-22.

6. Ткаченко В.І. Концепція повітряної операції в сучасних умовах збройної боротьби у повітрі / В.I. Ткаченко, Є.Б. Смірнов, В.О. Нерубацький // Наука і техніка Повітряних Сил Збройних Сил України. - 2014. - № 2(15). - С. 6-10. 
7. Жарик О.М. Критерії та показники ефективності повітряної операції, метою якої є завоювання переваги в повітpi / О.М. Жарик // Наука і техніка Повітряних Сил Збройних Сил України. - 2015. - № 3(20). - С. 15-20.

8. Горбенко В.М. Методичний підхід до визначення форм дій та способів застосування військових формувань у системі операцій збройних сил / В.М. Горбенко, В.В. Тюрін, О.А. Коршець // Наука і оборона. - 2019. - № 2. - С. 29-34. https://doi.org/10.33099/2618-1614-2019-7-2-29-34.

9. Артюх В.М. Перемога в повітрі - перемога у війні / В.М. Артюх, О.М. Жарик // Оборонний вісник. - 2020. № 12. - С. 8-12.

10. Жарик О.М. Військова операція Азербайджану в Нагірному Карабасі в контексті розвитку Повітряних Сил Збройних Сил України / О.М. Жарик, А.В. Тристан // Наука і техніка Повітряних Сил Збройних Сил України. - 2021. № 2(43). - C. 19-24. https://doi.org/10.30748/nitps.2021.43.02.

11. Еволюційні зміни у підходах щодо проведення повітряної наступальної операції на прикладі локальних конфліктів у Лівії (1986 рік, 2011 рік) / С.В. Лазебник, В.В. Тюрін, І.М. Тіхонов, В.В. Грідіна // Системи озброєння і військова техніка. - 2013. - № 4(36). - С. 142-145.

12. Горбенко В.М. Оцінювання можливих механізмів досягнення Російською Федерацією політичних цілей в Україні з використанням концепцій стратегічного паралічу та операцій на основі ефектів / В.М. Горбенко, О.А. Коршець, Н.О. Королюк // Збірник наукових праць Харківського національного університету Повітряних Сил. - 2020. - № 1(63). C. 113-123. https://doi.org/10.30748/zhups.2020.63.15.

13. Лазебник С.В. Розвиток оперативного мистецтва, форм та способів застосування Повітряних Сил / С.В. Лазебник, В.Г. Малюга, О.М. Місюра // Збірник наукових праць Харківського національного університету Повітряних Сил. - 2017. - № 5(54). - С. 15-18.

14. Спільна доктрина НАТО 3 повітряно-космічних операцій (АЈР-3.3) [Електронний ресурс]. - 100 с. Режим доступу: https://webcache.googleusercontent.com/search?q=cache:n739XXYuGvwJ:https://www.japcc.org/wpcontent/uploads/AJP-3.3-EDB-V1-E.pdf $+\& \mathrm{~cd}=3 \& \mathrm{hl}=\mathrm{ru} \& \mathrm{ct}=\mathrm{clnk} \& \mathrm{gl}=\mathrm{ua}$.

15. Доктрина Повітряні Сили Збройних Сил України [Електронний ресурс]. - 2020. - Режим доступу: http://www.hups.mil.gov.ua/assets/uploads/library/nadhodzhennya/sichen-berezen-2021/pdf/28.pdf.

Надійшла до редколегії 11.04.2021

Схвалена до друку 12.05.2021

\section{Bidомості про авторів:}

Жарик Олександр Миколайович

заступник начальника штабу

Повітряних Сил Збройних Сил України

Командування Повітряних Сил Збройних Сил України,

Вінниця, Україна

https://orcid.org/0000-0002-0915-4327

\section{Тристан Андрій Вікторович}

доктор технічних наук старший науковий співробітник начальник науково-дослідного управління

Харківського національного університету

Повітряних Сил ім. І. Кожедуба,

Харків, Україна

https://orcid.org/0000-0003-0494-8125
Information about the authors:

\author{
Oleksandr Zharyk \\ Deputy Chief of Staff \\ of the Air Force Command \\ of the Armed Forces of Ukraine, \\ Vinnytsia, Ukraine \\ https://orcid.org/0000-0002-0915-4327
}

\author{
Andrii Trystan \\ Doctor of Technical Sciences Senior Research \\ Chief of Scientific Research Department \\ of Ivan Kozhedub Kharkiv National \\ Air Force University, \\ Kharkiv, Ukraine \\ https://orcid.org/0000-0003-0494-8125
}

\title{
ВОЗДУШНАЯ ОПЕРАЦИЯ В ВОЕННЫХ КОНФЛИКТАХ СОВРЕМЕННОСТИ
}

\author{
А.Н. Жарик, А.В. Тристан
}

В статье определены основные тенденции развития воздушных операций в войнах (военных конфликтах) прошлого и современности. Доказано, что перемещение вооруженной борьбы в воздушное пространство поднимает роль авиационной и противовоздушной компонент вооруженных сил, от эффективности применения которых будет зависеть степень достижения стратегических иелей военных действий. Отмечается, что воздушная операция является важным компонентом операции по отражению вооруженной агрессии. Определено, что современная концепция воздушной операции должна повлиять на развитие военного искусства, организацию подготовки, дальнейшее реформирование и развитие Вооруженных Сил Украины и позволит качественно реформировать Воздушные Сильл и ускорить вступление Украины в НАТО. Основой успешного проведения воздушной операции является завоевание преимущества в воздухе. Потеря преимущества в воздухе ставит под сомнение успешность операции сил обороны государства с отпора вооруженной агрессии. При условии, если авиация и ПВО, другие силь и средства группировки объединенных сил (сил обороны) будут способны выполнить свои задачи в воздушной оборонительной операции - то есть в операции по борьбе за превосходство в воздухе с оборонительными целями, то и группировки Сухопутных войск будут иметь минимальные потери, сохранят свои боевые способности и будут способны выполнить задачи в оборонной (наступательной или контрнаступательной) операции, других операциях объединенных сил.

Ключевые слова: военные конфликты, преимущество (господство) в воздухе, воздушная операция, Воздушные Силы Вооруженных Сил Украины, система операчий. 


\section{AIR OPERATION IN MODERN MILITARY CONFLICTS}

\section{O. Zharyk, A. Trystan}

The article identifies the main trends in the development of air operations in wars (military conflicts) of the past and present. It has been proved that the movement of armed warfare into airspace raises the role of the aviation and anti-aircraft components of the armed forces, the effectiveness of which will determine the degree of achievement of the strategic goals of military operations. It is noted that the air operation is an important component of the operation to repel armed aggression. The paper considers the components of achieving the goal of an armed conflict (war), the evolution of the transformation of an air operation, the specifics of conducting an air operation of our time, the role and place of an air operation in the operation system of the Armed Forces of Ukraine. It has been proven that the conquest of air superiority (supremacy) is the first military (armed) stage in achieving the goals of the war. The features of the conduct of air operations by the armed forces of the NATO countries and their stages are considered. The article lists the types of air operations, defines the necessary conditions for conducting an air operation and formulates the requirements for the control system, which is created to perform the tasks of an air operation. It was determined that the modern concept of an air operation should influence the development of military art, the organization of training, further reform and development of the Armed Forces of Ukraine and will allow qualitatively reforming the Air Force and accelerating Ukraine's entry into NATO.A successful air operation is based on gaining air superiority. The loss of air superiority casts doub ton the success of the operation of the state defense forces to repulse armed aggression. Provided that aviation and air defense, other forces and means of the grouping of the joint forces (defense forces) are able to fulfill their tasks in an air defensive operation - that is, in an operation for air superiority with defensive purposes, then the grouping of the Ground Forces will have minimal losses, will retain their combat capabilities and will be able to perform tasks in a defensive (offensive or counter-offensive) operation, and other operations of the joint forces.

Keywords: military conflicts, advantage (supremacy) in the air, air operation, Air Force of the Armed Forces of Ukraine, system of operations. 